\title{
Administration comes in from the sun
}

\section{Washington}

The Carter Administration's image as a strong supporter of solar energy is going into eclipse. Last June the President committed the United States to the objective that 20 per cent of its energy should come from the sun by the year 2000; but the Administration is already discussing budget figures for solar research and development which, critics say, make this goal unachievable.

The source of the controversy is a memorandum leaked from the Department of Energy last month revealing current thinking on the evolution of the energy budget over the next five years. This shows an increasing share for nuclear and fossil energy - from 37 per cent of the budget in 1981 to 43 per cent in the period 1982-86 - and a corresponding drop from 24 to 20 per cent for solar energy and conservation efforts.

Defending these figures in front of a congressional committee last week, Energy Secretary Mr Charles Duncan pointed out that they were not firm commitments, but were intended as background to preparations for the 1982 budget request, and were likely to alter from year to year.

"I believe we are on track toward achieving the nation's solar goals', $\mathrm{Mr}$ Duncan said. "But I believe it is unrealistic to assume, as some do, that we can lay out a detailed and precise road-map that tells us what is going to happen year by year for the next twenty years."

Given the vagaries of technological forecasting, Mr Duncan's logic is not disputed. But according to published and unpublished documents produced by committee chairman Representative Richard Ottinger, at least some $\mathrm{DoE}$ officials and their outside advisers feel there is a growing gulf between the political rhetoric surrounding long-term goals, and the political realities of short-term budget choices.

At the centre of the dispute is President Carter's 20 per cent target, itself based on a study carried out by White House staff and the DoE. Presented with various policy options, the President selected the "maximum practical goal" of 18.5 quads of solar energy by 2000 , when total energy demand is expected to reach 95 to 100 quads. Politically, this was judged the least that the vociferous solar lobby, which had pushed for an even larger commitment, would accept, and the most that sceptics within the Administration could live with.

The President admitted that achieving the goal would require not only substantial cooperation from the private sector, but also a vigorous and sustained commitment by the federal government.

It is the desirability of this federal involvement that has since been challenged, particularly in a period of budget stringencies and of pressure to reduce public participation in potentially commercial programmes.

Earlier this year, for example, the Committee on Nuclear and Alternative Energy Systems of the National Academy of Sciences aroused the anger of solar advocates with a report claiming that the President's goals could be approached only by federal subsidies far higher than those currently given to other energy sources. The issue has been sharpened by the tightening of budget constraints.

The detailed expenditure proposals in last year's White House review are substantially higher than those being considered by the DoE. Thus, the policy review suggested that biomass could be contributing 5.4 quads a year by the end of the century, but that an investment of at least $\$ 150$ million a year over the next five years would be needed. In contrast, the DoE estimates reckon on a more modest budget of $\$ 60$ million a year over this period.

What angers the critics most, however, is not so much the precise levels of proposed funding as broader evidence that the Department of Energy may not be giving adequate attention to the solar and conservation fields.

Here they are supported by two recent reports from congressional review agencies, the General Accounting Office and the Office of Technology Assessment, both of which take the DoE to task for failing to take the steps necessary to

implement the Administration's solar goals.

The OTA report, for example, published in Washington last week, concludes that solar and conservation programmes are hampered by a lack of direction and leadership.

Energy Secretary Duncan admitted at last week's hearing that such management problems had existed in the past, but listed recent steps he had taken to resolve them.

Duncan also listed the Administration's achievements in solar energy, quoting the \$36 million recently awarded for the installation of solar heating and cooling systems in federal buildings, and contracts for nine major photovoltaic systems in commercial and industrial settings.

Solar advocates are not overly impressed. They point out that, although the Administration can demonstrate a spectacular rise in support for solar energy from a few million dollars in the early 1970 s to a proposed budget of $\$ 1,400$ million in 1981 , Congress has led the way.

For two years things looked different, with positive discrimination apparently flowing from the White House in favour of solar energy as an alternative to less environmentally-acceptable options. Last month's leak may result in a small increase in the solar budget request when it comes formally to Congress next January. Otherwise, it looks as if it will be business as usual.

David Dickson

\section{Polish chemist gets off lightly}

Miroslaw Chojecki, a young Polish chemist and campaigner for academic freedom, last week went on trial in what Polish intellectual circles regard as a test case - and received as near as the authorities could come to an acquittal.

Chojecki was formerly employed at the Swierk nuclear research centre near Warsaw. In 1976, he became a member of the "Workers' Defence Committee" (an unofficial human rights group), and shortly afterwards was dismissed from his job. Since then, he said before his trial last week, he has been allowed no access to any scientific libraries or periodicals. With his own academic career at an end, Chojecki and a few friends founded, in 1977, the "Independent Publishing Enterprise, NOWA", which strives to fill the gap caused by what he described as the state monopoly of information.

In particular, NOWA has published several textbooks for the underground "Flying University" - a dissident educational self-help body which, although specialising in the social sciences and humanities, numbers among its patrons some of the most distinguished Polish natural scientists.
(Its "Dean", Professor Jan Kielanowski, is a member of the official Polish Academy of Sciences, and a world authority on animal nutrition.)

Not surprisingly, the "Flying University" came out strongly with an open letter in Chojecki's defence. Tacit support from the scientific community at large, said Chojecki, was even more widespread. On two occasions, leaflets calling for his acquittal were discharged over central Warsaw from a catapult mounted on the building of the Academy of Sciences itself.

The formal charges against Chojecki were misappropriation of a duplicator and incitement to induce two employees of a state printing concern to print a dissident work. In fact, as he stated in his 2000-word defence, everyone in court was aware that the whole issue of intellectual freedom was on trial. Chojecki made no effort to deny his publishing activities - he even submitted as evidence the catalogue of works he had produced. After an 11-hour hearing, he received an 18-months suspended sentence, and a fine which was waived in consideration of his pre-trial spell in prison. 